\title{
Diurnal Variation of Convective Activity over the Tropical Western Pacific
}

\author{
By Tsuyoshi Nitta and Sota Sekine
}

Center for Climate System Research, University of Tokyo, 4-6-1 Komaba, Meguro-ku, Tokyo 153, Japan

(Manuscript received 25 January 1994, in revised form 17 June 1994)

\begin{abstract}
Diurnal variations of convective activities in the tropical western Pacific are examined by using 3hourly geostationary meteorological satellite data acquired over a 9-year period (1980-1989). Large diurnal variations of convection exist over continents, large islands and their adjacent sea regions such as the Indochina Peninsula, the Tibetan Plateau, North Australia and the maritime continent regions. Large diurnal variations are also found over the Bay of Bengal and the South China Sea. Although the diurnal variation is less pronounced over the open oceanic regions east of $150^{\circ} \mathrm{E}$ than over the maritime continent regions, moderate amplitudes of diurnal variations are observed over the Intertropical Convergence Zone ( ITCZ) and the South Pacific Convergence Zone (SPCZ). Features of the diurnal variation vary with the seasons and it is enhanced during seasons in which mean convective activities become strong.

Over continents and large islands, the convection attains its maximum intensity in late afternoon to evening, probably due to strong surface heating during daytime. Over sea areas in the vicinity of large islands, the maximum convective activity generally occurs in the morning. It is suggested that the interaction between land-sea circulations and large-scale environmental flows may produce a diurnal cycle in the offshore convection.

There exist large amplitudes of diurnal variations over the head of the Bay of Bengal during the Indian summer monsoon season with the maximum amplitude in the afternoon. The diurnal cycle of convection becomes predominant during summer and fall over the South China Sea, with the maximum convective activity near local noontime.

The convection over the ITCZ and the SPCZ has a maximum intensity in the morning, in general, but a secondary maximum of convection occurs in the afternoon. The Fourier analysis of the second component (semi-diurnal variation) suggests that there exist semi-diurnal variations of convection over the ITCZ and the SPCZ with maximum peaks around 3-4 LST and 15-16 LST.
\end{abstract}

\section{Introduction}

The tropics play an important role in maintaining atmospheric general circulations as a heat engine. Heat sources in the tropics are mostly due to condensation heating generated in a large number of cumulus clouds. Usually in the tropics individual cumulus clouds are organized into larger-scale systems such as cloud clusters, super cloud clusters and wave disturbances. These organized convective systems vary with different time scales ranging from a few hours to months.

Among the various time scales of tropical convection, diurnal variations have been known as one of the prominent variations. Diurnal variations of rainfall over the different tropical land areas have been reported by many investigators (e.g., Ramage, 1964; Nieuwolt, 1968; Haldar et al., 1991; Oki and Musiake, 1994). Quite recently, Oki and Mushiake (1994) have extensively investigated the diurnal cy-

(C) 1994, Meteorological Society of Japan cle of precipitation over the Malay Peninsula based on surface hourly observations. They found that there exist large diurnal variations of precipitation, but phases of the diurnal cycle are different between the inland regions and the coastal regions over the Malay Peninsula. Brier and Simpson (1969) showed the existence of semi-diurnal variations of cloudiness and rainfall in the tropical western Pacific and linked these variations with the semi-diurnal solar atmospheric tide. Gray and Jacobson (1977) and McBride and Gray (1980) analyzed the diurnal cycle of deep cumulus convection over the tropical oceanic areas such as the western Pacific and the western Atlantic and found that heavy rainfall is 2-3 times greater in the morning than in the late afternoonevening at many places. They hypothesized that the morning maximum of deep convection is a result of radiation balance between convective regions and its surrounding cloud-free regions.

McGarry and Reed (1978) applied a harmonic analysis to the satellite infrared (IR) and precipi- 
tation data during the GARP Atlantic Tropical Experiment (GATE) to determine the diurnal variation in convective activity and precipitation. They found that rain amounts and convective activity become greatest around midnight over the African land area, but in the early afternoon over the GATE ship array. Similar analyses of diurnal variations of cloudiness and precipitation over the GATE area were performed by many authors (Asplinden et al., 1976; Grueber, 1976; McGarry and Reed, 1978; Murakami, 1979 and Ball et al., 1980).

Houze et al. (1981) demonstrated, based on Winter Monsoon Experiment (WMONEX) data, that the maximum radar echo coverage takes place at 23 LST over land and 8 LST over sea in the vicinity of northern Borneo. They concluded that the diurnal cycle of the offshore convection is generated by interaction between land breeze from Borneo and low-level northeasterly monsoon flow.

Murakami (1983) first examined spatial distributions of the diurnal variations of the deep convection over the western Pacific and the Southeast Asia during the FGGE period based on IR data observed by the geostationary meteorological satellite (GMS) of Japan. It was shown by his analysis that the convective activity over land is greatest at around $18 \mathrm{LST}$, but in the morning over the adjacent oceanic areas. Augstein (1984) and Albright et al., (1985) made similar analyses of the diurnal variation of deep convection over the central Pacific Ocean during the FGGE period using the GOES-West IR satellite data. They found that a prominent afternoon maximum occurred in some regions, but a morning maximum prevailed in other regions. They also noted the existence of a semi-diurnal component of convective activities over the oceanic regions.

Previous observational results mentioned above showed that there exist large regional and seasonal differences in the diurnal variations of convection, both in amplitude and phase. Since surface observations of precipitation and radar echoes are very limited in the tropical regions, satellite observations should be more extensively used for the analysis of the diurnal cycle of convection. Although the investigators mentioned above have used satellite data for the analysis of the diurnal variation, their results are limited in periods and locations. In this study more detailed features of the diurnal cycle of tropical convection will be analyzed based on longperiod GMS IR data. Since the analysis errors are usually reduced in proportion to the square root of the total number of observations, using 9-year data in this study may reduce analysis errors by about one-third by comparison with using only one-year data as have been analyzed by most previous investigators. Not only spatial characteristics but also seasonal changes of the diurnal variations will be presented.

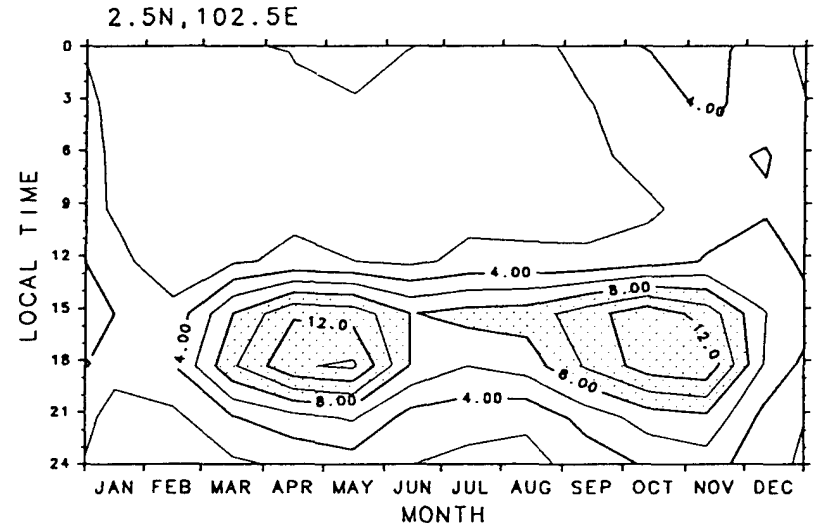

Fig. 1. Local time-season section of $I_{C}$ in the inland area $\left(2.5^{\circ} \mathrm{N}, 102.5^{\circ} \mathrm{E}\right)$ in the Malay Peninsula.

The Tropical Rainfall Measuring Mission (TRMM) will be launched in 1997 under the joint science program between Japan and U.S.A. to measure 3-dimensional distributions of tropical precipitation from space. One of the scientific objectives of TRMM is to estimate the diurnal cycle of tropical rainfall quantitatively. This study corresponds to pre-TRMM research work and will contribute to the scientific plans for TRMM.

\section{Data and method of analysis}

3-hourly IR- $T_{B B}$ (infrared equivalent blackbody temperature) data for 9 years (1980-1990, except for 1984) derived from GMS are utilized for analysis. $T_{B B}$ data are obtained at $1^{\circ} \times 1^{\circ}$ grid points.

In order to determine the activities of deep convective clouds, we use the following index $I_{C}$ at each grid point defined by

$$
\begin{aligned}
I_{C} & =250-T_{B B}: T_{B B}<250 \mathrm{~K} \\
& =0 \quad: T_{B B}<250 \mathrm{~K},
\end{aligned}
$$

where $250 \mathrm{~K}$ generally corresponds to the air temperature around $400 \mathrm{hPa}$ and thus $I_{C}$ represents an index for deep convective clouds whose top height exceeds about $400 \mathrm{hPa}$. Eq. (1) not only picks up convective activity due to deep clouds, but also eliminates the effects of surface temperature.

Using 3-hourly $I_{C}$ data for 9 years, 9-year averaged values of $I_{C}$ are computed at each 3 hourly UT observation time for each calendar month (January,..., December). Then Fourier analysis is applied to 8 mean $I_{C}$ values for one day to determine amplitudes and phases of the first (diurnal) and the second (semi-diurnal) components. Phases (times for maximum $I_{C}$ ) for the two components are adjusted to the local time at each grid point. Local time-season cross sections of $I_{C}$ are constructed in several important regions to examine seasonal changes of the diurnal cycle. 
(a)

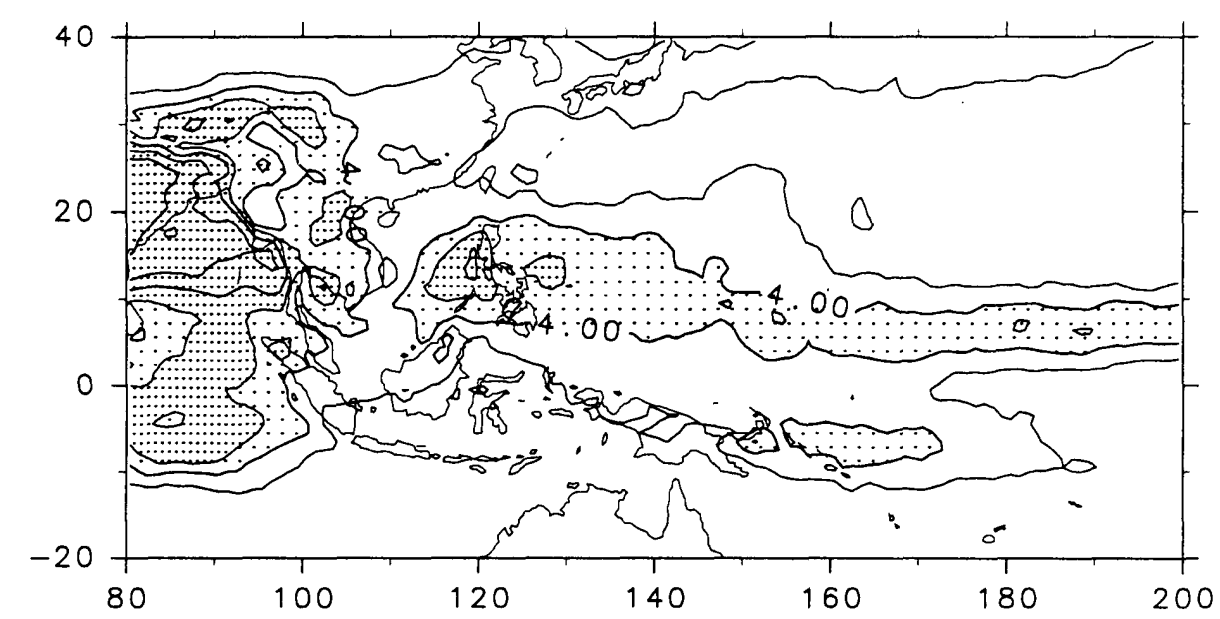

(b)

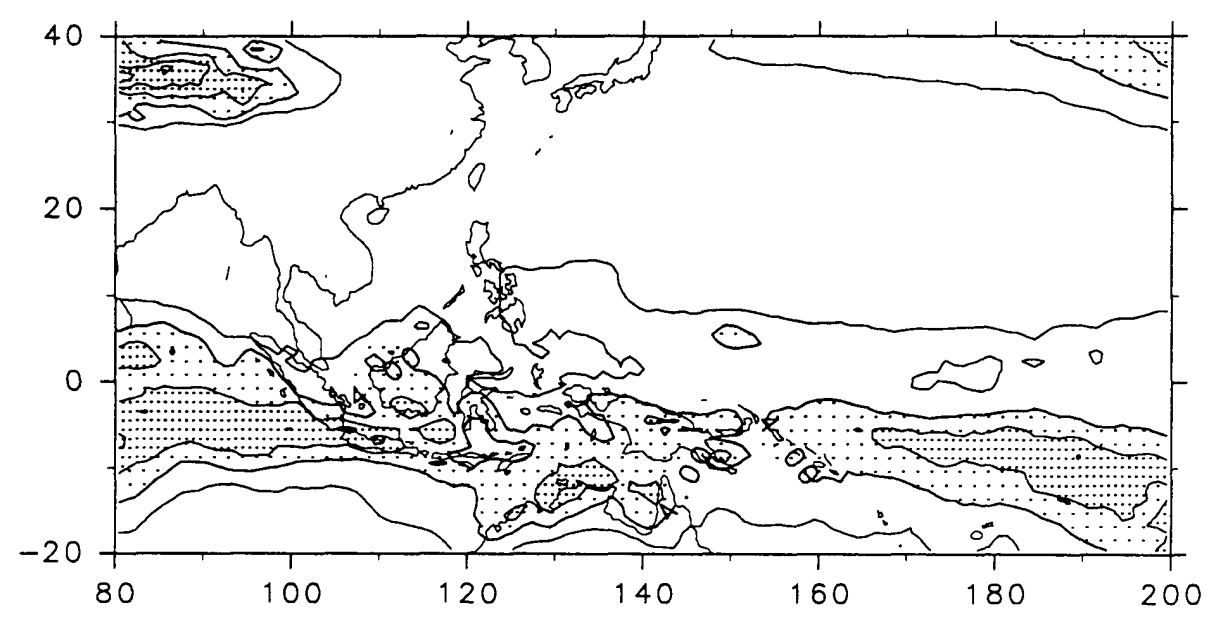

Fig. 2. Mean horizontal distributions of $I_{C}$ in July (a) and January (b). The contour interval is 2.0 and light and heavy shaded regions correspond to regions larger than 4.0 and 6.0, respectively.

Maruyama et al. (1986) utilized monthly mean high-cloud-amount data derived from GMS which generally correspond to $I_{C}$ used in this study to examine a relationship with precipitation. They obtained a strong linear relationship between two parameters. Their results indirectly suggested that $I_{C}$ defined by Eq. (1) could be used as an index of deep convective clouds producing precipitation. In order to check whether $I_{C}$ values defined by Eq. (1) really represent the convective activity, we compare $I_{C}$ with precipitation observed by surface raingauges over Malaysia analyzed by Oki and Mushiake (1994). They investigated seasonal changes of the diurnal cycle of precipitation over Malaysia using groundbased hourly observations for 10 years (1981-1990). They found that there exists a pronounced diurnal cycle of precipitation with peaks around May and October in season and around 15-16 LST in time of day over the inland region of the Malay Peninsula. Figure 1 shows the local time-season section of $I_{C}$ at $2.5^{\circ} \mathrm{N}, 102.5^{\circ} \mathrm{E}$ corresponding to the inland region which Oki and Mushiake (1994) analyzed. $I_{C}$ has two peaks around May and October which are consistent with the results of the precipitation obtained by Oki and Mushiake (1994). However, $I_{C}$ has a peak around 17-18 LST which is about 2 hours later than that of the precipitation. This time lag between the two parameters may be due to the fact that the cloud cover may expand further for about a few hours even after the the convective system reaches the maximum intensity (maximum rainfall). The comparative study between $I_{C}$ and the surface precipitation over the Malay Peninsula indicated that $I_{C}$ can be used for the analysis of the diurnal cycle of the convective activity, although there may exist a few hours time lag between $I_{C}$ and 
(a)
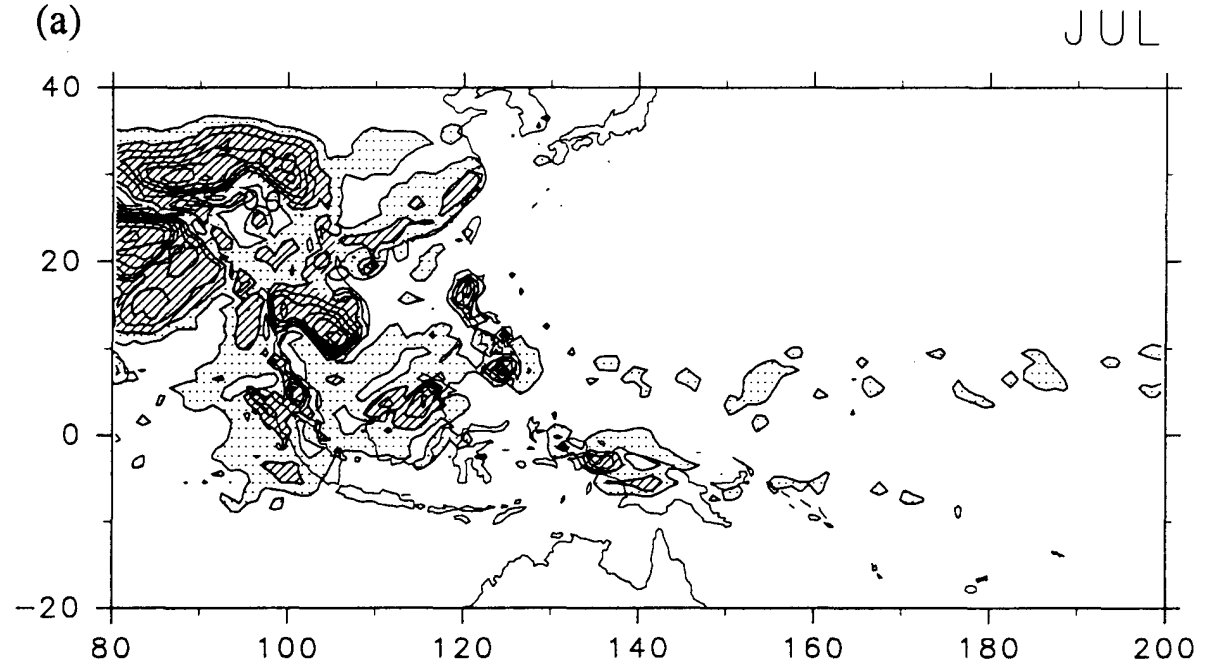

(b)

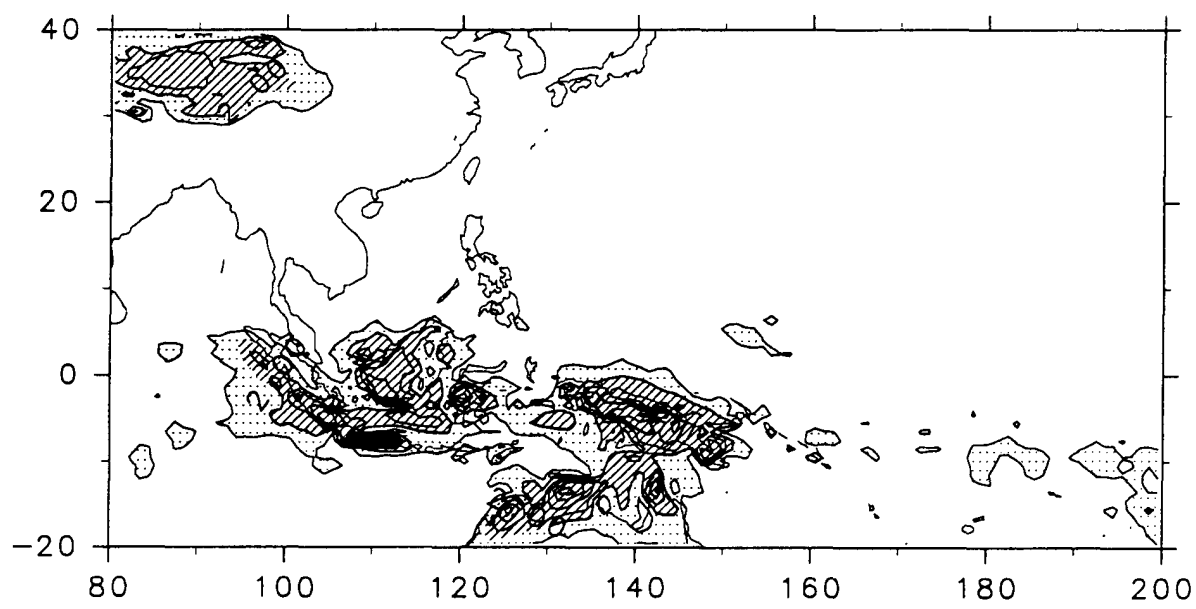

Fig. 3. Horizontal distributions of amplitudes of diurnal components of $I_{C}$ in July (a) and January (b). The contour interval is 1.0 and heavy shaded regions denote regions larger than 2.0.

precipitation.

\section{Spatial characteristics of diurnal varia- tions}

Diurnal variabilities of the convective activity may be related to the total intensity of the convective activity itself. Figure 2 shows horizontal distributions of the 9-year averaged $I_{C}$ for July, and January. During July active convection is mostly found in the northern tropical regions, such as the Bay of Bengal, the Indochina Peninsula, the Philippine Sea and the ITCZ. Active convection also exists to the east of New Guinea, corresponding to the SPCZ. In January, active convective regions move to the southern tropical regions and extend in the east-west direction along Eq. $-10^{\circ} \mathrm{S}$. Especially the convection over the SPCZ is greatly enhanced, while the convective activity over the ITCZ is reduced.
Figure 3 shows the horizontal distributions of the amplitudes of the diurnal cycle of $I_{C}$ for July and January. During the northern summer, large diurnal variations exist over the continental regions such as the Tibetan Plateau and the Indochina Peninsula. Large amplitudes are also found over the head of the Bay of Bengal and in the vicinity of large islands such as Borneo, Sumatra and New Guinea. Some large diurnal variations can be seen along the ITCZ and the SPCZ. During the northern winter, large amplitudes are concentrated in the maritime continent regions and over North Australia. Some amplitudes can be found along the SPCZ extending eastward from about $160^{\circ} \mathrm{E}$. Large magnitudes of mean values and the diurnal cycle of $I_{C}$ found over the Tibetan Plateau in January (Figs. $2 \mathrm{~b}$ and $3 \mathrm{~b}$ ) are not due to convection, but due to the low surface temperature and its diurnal variations. 
(a) DIURNAL VARIATION OF I C

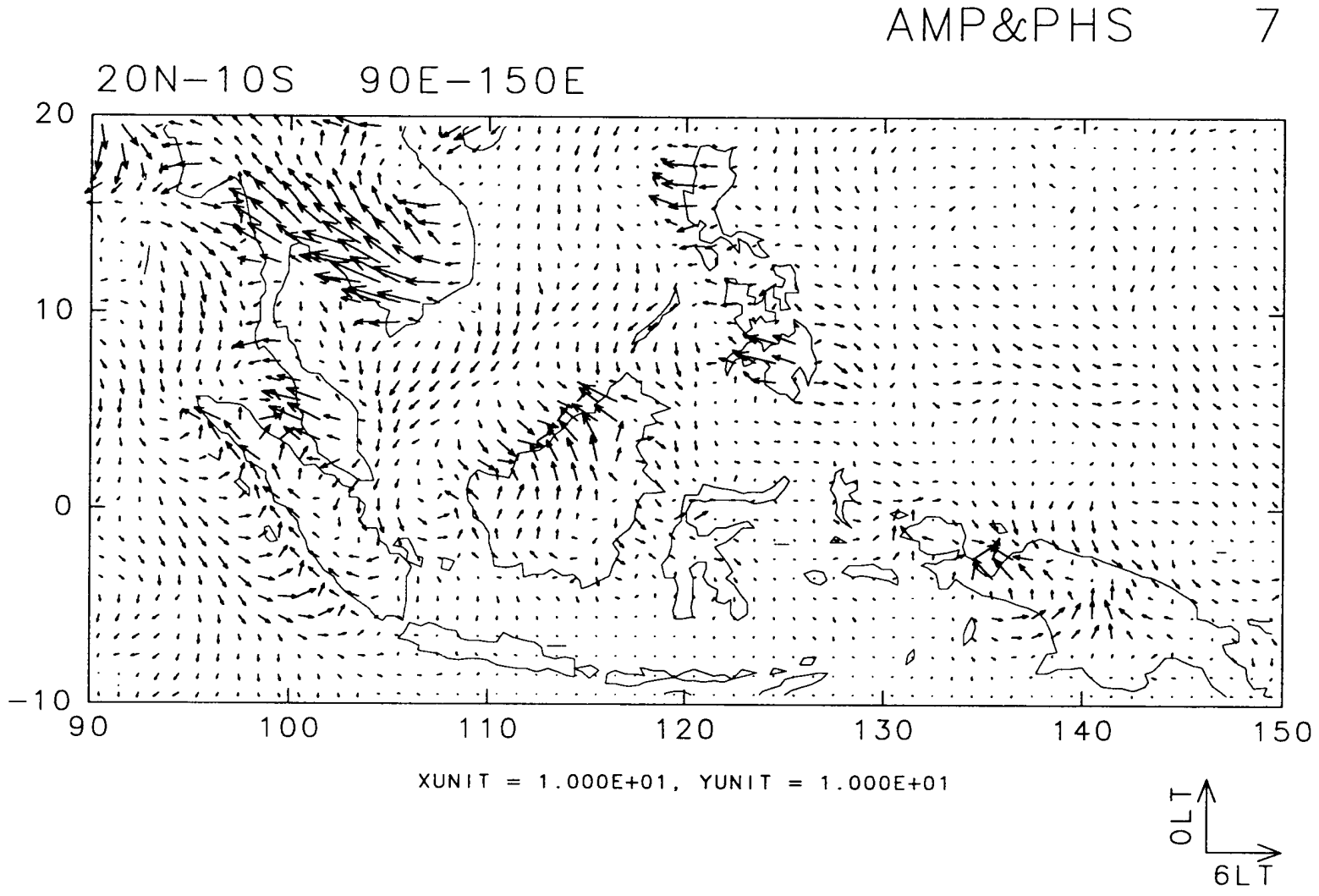

(b) DIURNAL VARIATION OF I C

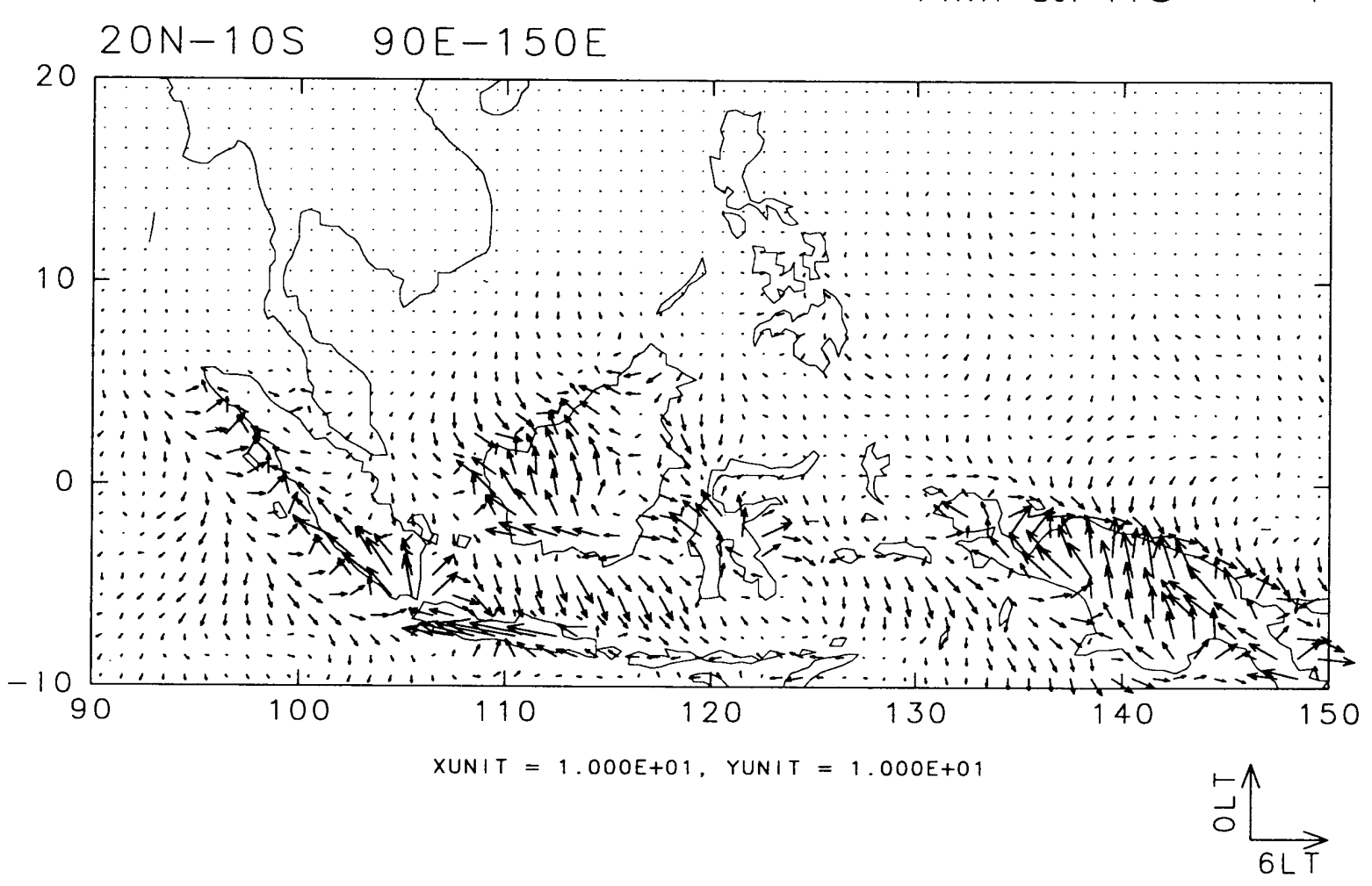

Fig. 4. Amplitudes and phases of diurnal components of $I_{C}$ represented by vector forms in the maritime continent regions in July (a) and January (b). Units of amplitudes are 10 shown in right-lower corner and the phase corresponds to the local time of the maximum $I_{C}$. 
NORTHWEST BORNEO

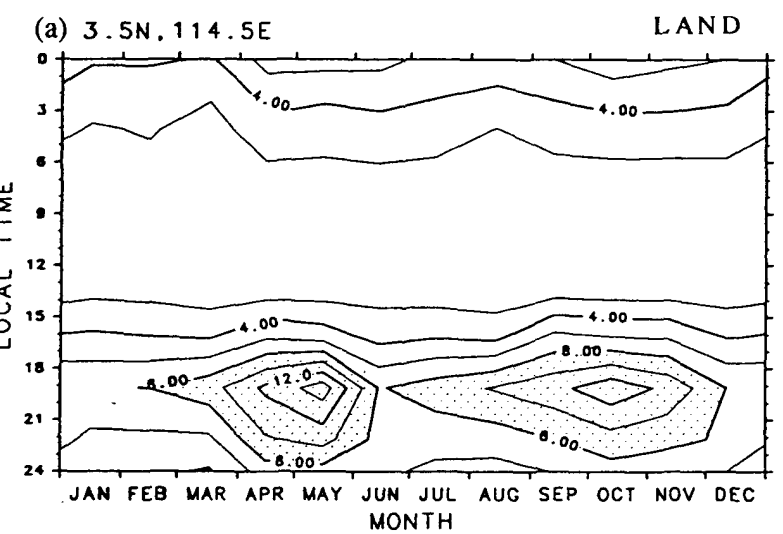

(b) $3.5 \mathrm{~N}, 112.5 \mathrm{E}$

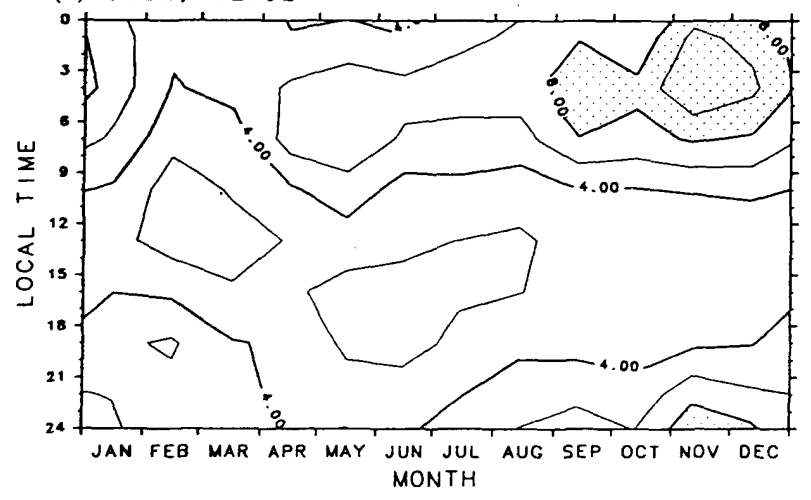

NORTH JAVA

(c) $7.55 .111 .5 \mathrm{E}$
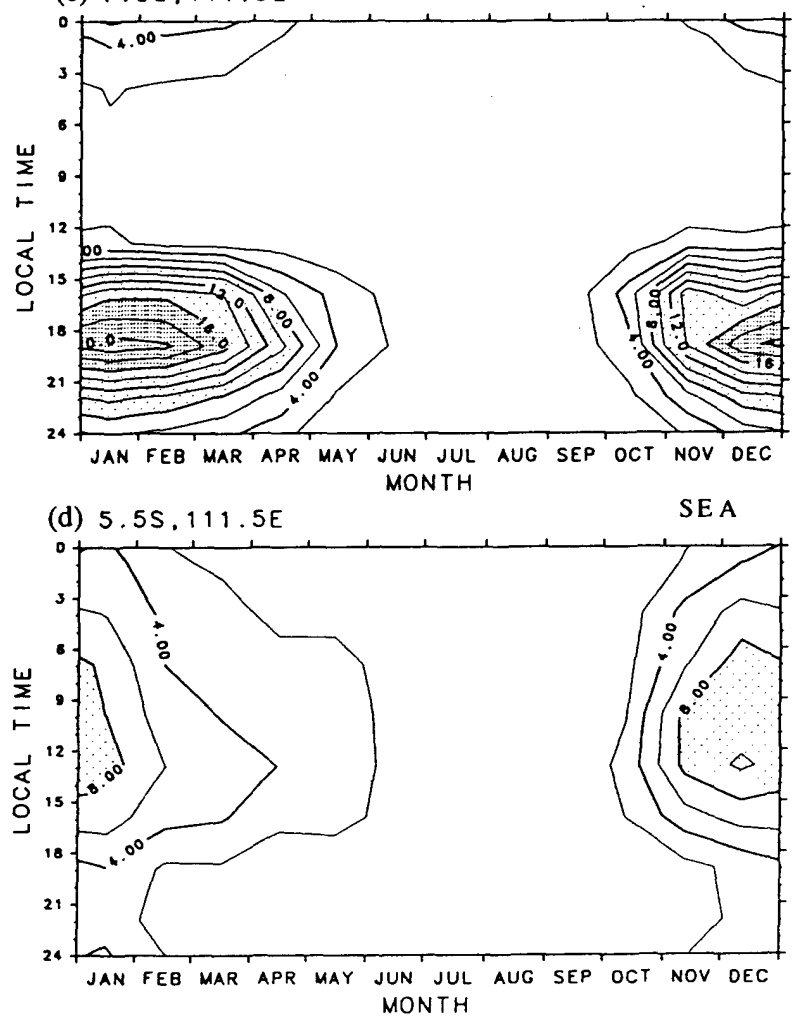

Fig. 5. Local time-season sections of $I_{C}$ over land and sea areas in the vicinity of the Northwest Borneo $(a, b)$ and the North Java $(c, d)$.

These results indicated that diurnal variations of convection are mostly dominant in continental regions, and over and nearby large islands in the maritime continent regions, suggesting that the strong surface heating during daytime may play an important role in the diurnal cycle over land areas. Moderate amplitudes of the diurnal cycle can be seen in the open oceanic regions along the ITCZ and the SPCZ where convection itself is quite intense. The results of Figs. 2 and 3 show that the diurnal variability of $I_{C}$ generally accounts for about $80 \%$ or more of the mean $I_{C}$ over continents and large islands, but only about $20 \%$ over the ITCZ and the SPCZ.

The results of the diurnal cycle of $I_{C}$ for individual years (not shown) are generally similar to those for the 9-year averages over continents and large islands, but vary to some degree from year to year over oceanic regions probably due to interannual variations of convective activities.

In the following two sections we examine more detailed features of the diurnal variation over the maritime continent regions and over the open oceanic regions east of $140^{\circ} \mathrm{E}$.

\section{Diurnal variations over the maritime con- tinent and adjacent sea regions}

In this section, spatial and seasonal variations of the diurnal cycle over the maritime continent regions including the Indochina Peninsula, the Bay of Bengal and the South China Sea are described in detail. Figure 4 shows spatial distributions of amplitudes and phases (local time of maximum convective activity) described by vector forms in the region of $20^{\circ} \mathrm{N}-10^{\circ} \mathrm{S}$ and $90^{\circ} \mathrm{E}-150^{\circ} \mathrm{E}$ for July and January. In July, large diurnal variations are found over the Indochina Peninsula and large islands, where the diurnal cycle has peaks generally in the evening. Large diurnal variations also exist in the sea regions nearby large islands where peaks take place generally in the morning. There exist large amplitudes in the Bay of Bengal, where the maximum convective activity occurs near local noon. There also exist large amplitudes in the South China Sea, where the peak activity takes place in the early afternoon. Diurnal variations over the open oceanic areas east of about $130^{\circ} \mathrm{E}$ are weaker than those over the continent and maritime continent regions, but some amplitudes can be seen along the ITCZ in $5^{\circ}-10^{\circ} \mathrm{N}$ with peaks in the morning.

In January, large amplitudes are found over large 
islands such as Borneo, Sumatra, Java and New Guinea and the maximum activity mostly occurs in late evening. Large amplitudes are also found in the sea areas nearby large islands, but the maximum activity takes place mostly in the morning. There exist large diurnal variations over seas between large islands, such as the Java Sea and the Banda Sea.

In order to see more details of the land-sea contrast of the diurnal cycle near the large islands, local time-season sections of $I_{C}$ are examined in the vicinity of northwestern Borneo and northern Java (Fig. 5). Over the inland area of northwestern Borneo (Fig. 5a) the convection becomes most active around May and October, corresponding to semi-annual rainy seasons. During active convection seasons, maximum convection takes place around 19 LST. Over its adjacent sea area (Fig. 5b), the convection becomes most dominant in November with maximum amplitudes around 3 LST. Similar late afternoon peaks of the diurnal cycle can be seen over inland of northern Java during NovemberApril, corresponding to the southern summer season (Fig. 5c). On the other hand, the maximum diurnal cycle is found near noon in the Java Sea (Fig. 5d).

Houze et al. (1981) obtained an extremely regular diurnal cycle for the convective activity in northern Borneo during the international Winter Monsoon Experiment (WMONEX). They observed, based on radar and satellite observations, that the maximum convective activity occurs in late evening over land, but in the morning over sea. In order to confirm their results using long-period GMS data, we pick up the diurnal cycle of $I_{C}$ in December over land and sea areas which correspond to their analysis areas (Fig. 6). There exist large diurnal cycles, with peaks in late evening over land and in the morning over sea. These results are generally consistent with those obtained during the WMONEX. The results in Fig. 6 demonstrate that the diurnal variability in the vicinity of large islands such as Borneo accounts for about $70 \%-100 \%$ of the total convective activity.

The late evening peak of the diurnal cycle over large islands such as Borneo may be generated by the surface heating during daytime. It may take several hours for organized convective systems to reach maximum intensity. Probably, the maximum areal coverage of clouds lags by a few hours the maximum convective intensity, as discussed previously, resulting in maximum peak of $I_{C}$ in late evening. Houze et al. (1981) suggested that the morning peak over sea areas in northern Borneo is resulted from the interaction between land breezes and a monsoonal northeasterly flow. Our results for 9 years over the adjacent sea area of northwestern Borneo (Fig. 5b) indicated that the diurnal cycle of $I_{C}$ with morning peaks is intensified during the winter season, consistent with the results by Houze et al. (1981). How-
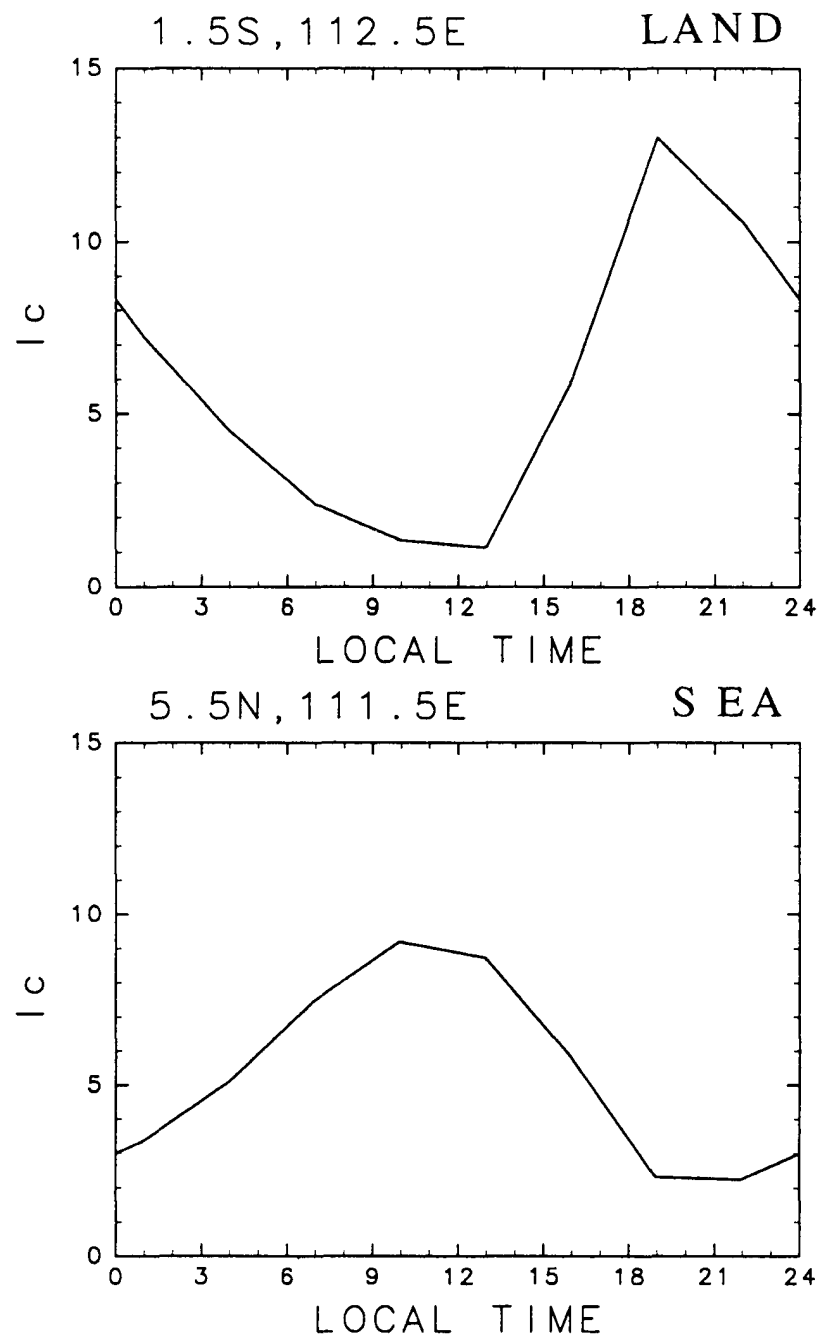

Fig. 6. Diurnal cycles of $I_{C}$ over land (upper) and sea (lower) in the West Borneo.

ever, the morning peak appears also during other seasons. It may be that morning peaks over sea areas in the maritime continent regions are generated due to the interaction between land-sea circulations and large-scale environmental flows. The results of seasonal mean winds analyzed by Matsumoto (1992) indicated that the $850-\mathrm{hPa}$ wind is a westerly blowing from sea areas to land areas in northwestern Borneo during November in which a strong morning peak is found over sea areas, but that an easterly wind blows from land to sea during March in which the morning peak becomes obscure. These results suggest that the large-scale wind direction blowing to or from sea areas may be important to generate the offshore convection, but further detailed analysis of wind fields associated with the diurnal cycle of convection may be needed to clarify the mechanism of the morning peak in sea areas around large islands. 
(a) $10.5 \mathrm{~N}, 105.5 \mathrm{E}$

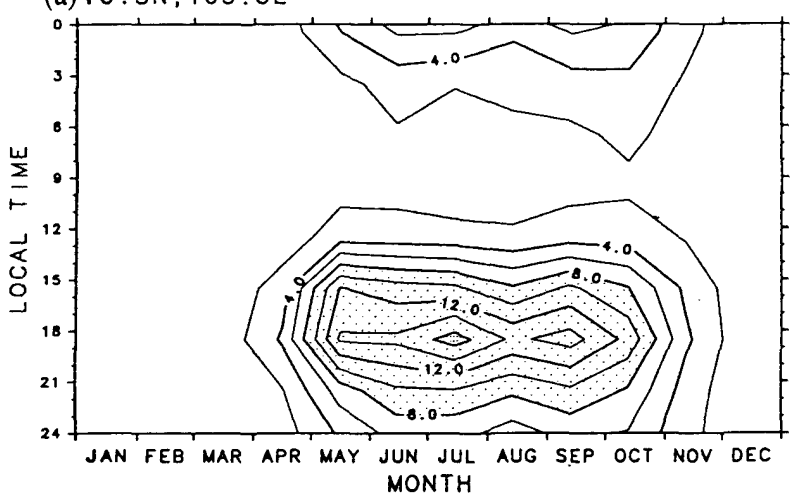

(b) $15.5 \mathrm{~N}, 88.5 \mathrm{E}$

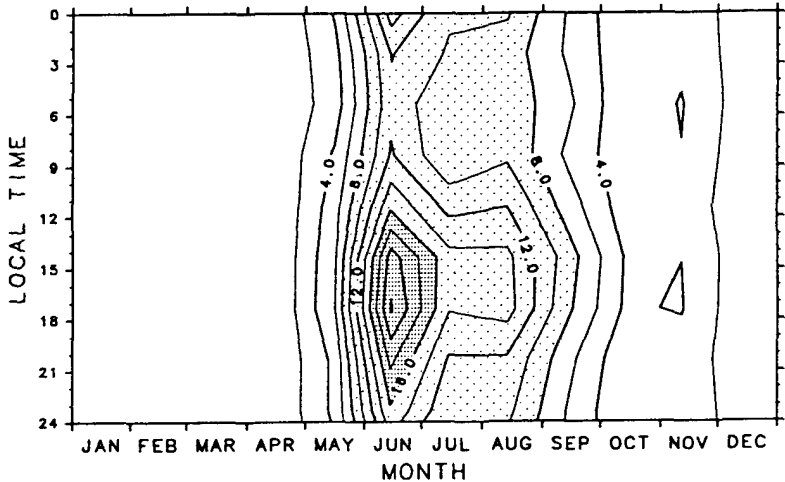

$10.5 \mathrm{~N}, 113.5 \mathrm{E}$

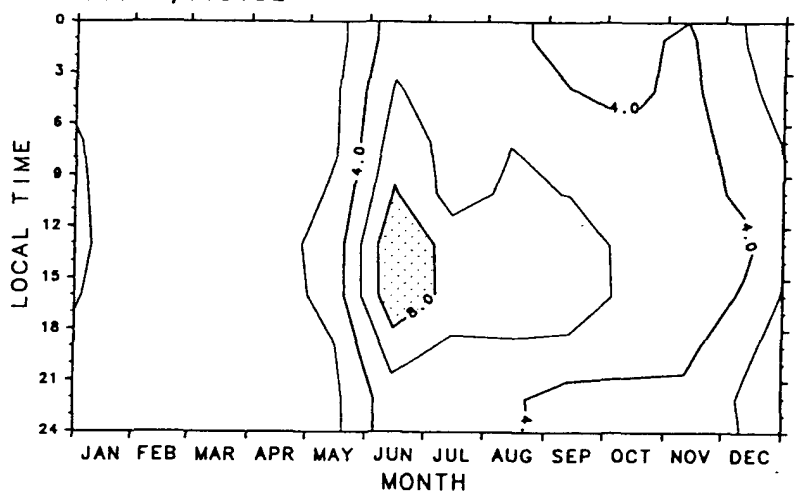

(d) $3.5 \mathrm{~S}, 93.5 \mathrm{E}$

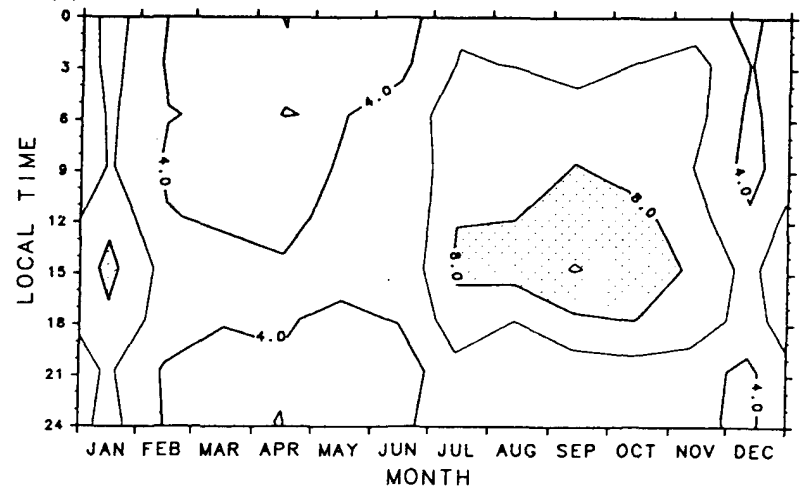

Fig. 7. Local time-season sections of $I_{C}$ in the Indochina Peninsula (a), the Bay of Bengal (b), the South China Sea (c) and the equatorial Indian Ocean (d).

Figure 7 shows local time-season sections of $I_{C}$ over the Indochina Peninsula, the Bay of Bengal, the South China Sea and the equatorial Indian Ocean. Over the Indochina Peninsula (Fig. 7a), intense convection develops during the rainy season from May to October, with peaks at about $18 \mathrm{LST}$ probably due to the strong surface heating during daytime. Over the Bay of Bengal (Fig. 7b), there exist extremely large diurnal cycles with peaks near $18 \mathrm{LST}$ during summer months, especially in June in which Indian monsoon starts. Spatial distributions of the diurnal variation over the Bay of Bengal and its surrounding areas (not shown) suggest that the diurnal cycle over these regions may be affected by the complicated land-sea contrasts such as the Indian Subcontinent, the Indochina Peninsula and the Bay of Bengal. The diurnal cycle over the South China Sea (Fig. 7c) becomes dominant during the summer monsoon season, and the maximum amplitude is found near noontime. Over the equatorial Indian Ocean (Fig. 7d), convection is active during JulyOctober with peaks around 12-15 LST. Although Murakami (1983) indicated the existence of diurnal variations of deep convection over the Bay of Bengal, the South China Sea and the equatorial Indian Ocean during summer, based on the FGGE data, detailed spatial and seasonal features of the diurnal variation of convection over these regions have been demonstrated for the first time in this study. However, the mechanism generating large diurnal variations of convection in the above sea areas is not clear and further studies may be required in the future.

\section{Diurnal and semi-diurnal variations over the ITCZ and the SPCZ}

In this section we investigate characteristic features of diurnal variations over the open oceanic regions east of the maritime continent. Figure 8 shows horizontal distributions of amplitudes and phases of the diurnal cycle for July and January in the region of $15^{\circ} \mathrm{N}-15^{\circ} \mathrm{S}, 140^{\circ} \mathrm{E}-160^{\circ} \mathrm{W}$. In July, active convective regions extend in the east-west direction both in $5^{\circ} \mathrm{N}-10^{\circ} \mathrm{N}$ and $5^{\circ} \mathrm{S}-10^{\circ} \mathrm{S}$, corresponding to the ITCZ and the SPCZ, respectively (Fig. 2a). Diurnal components over most of the ITCZ and the SPCZ regions in July have maximum peaks in late morning, but afternoon peaks appear in some regions. There exists little diurnal cycle over oceanic regions other than the ITCZ and the SPCZ. This may be due to the fact that $I_{C}$ defined by Eq. (1) corresponds to deep convection whose activity is mostly limited to the ITCZ and the SPCZ.

The diurnal cycle also appears in January over the ITCZ and the SPCZ, but the amplitude over 
(a) DIURNAL VARIATION OF I C $15 N-15 S \quad 140 E-160 W$

$$
\text { AMP\&PHS } 7
$$

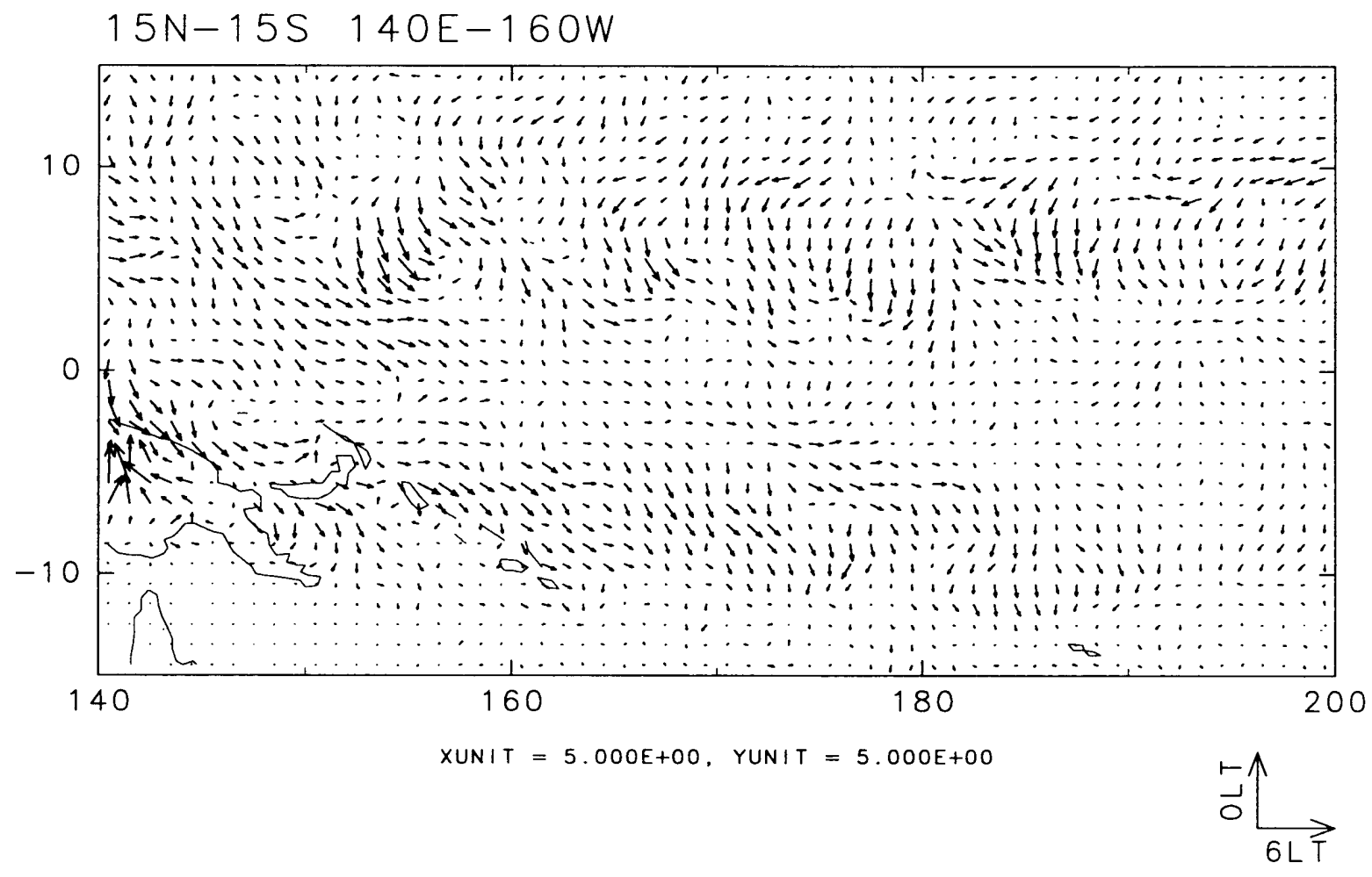

(b) DIURNAL VARIATION OF I C

\section{AMP\&PHS 1}

$15 N-15 S \quad 140 E-160 W$

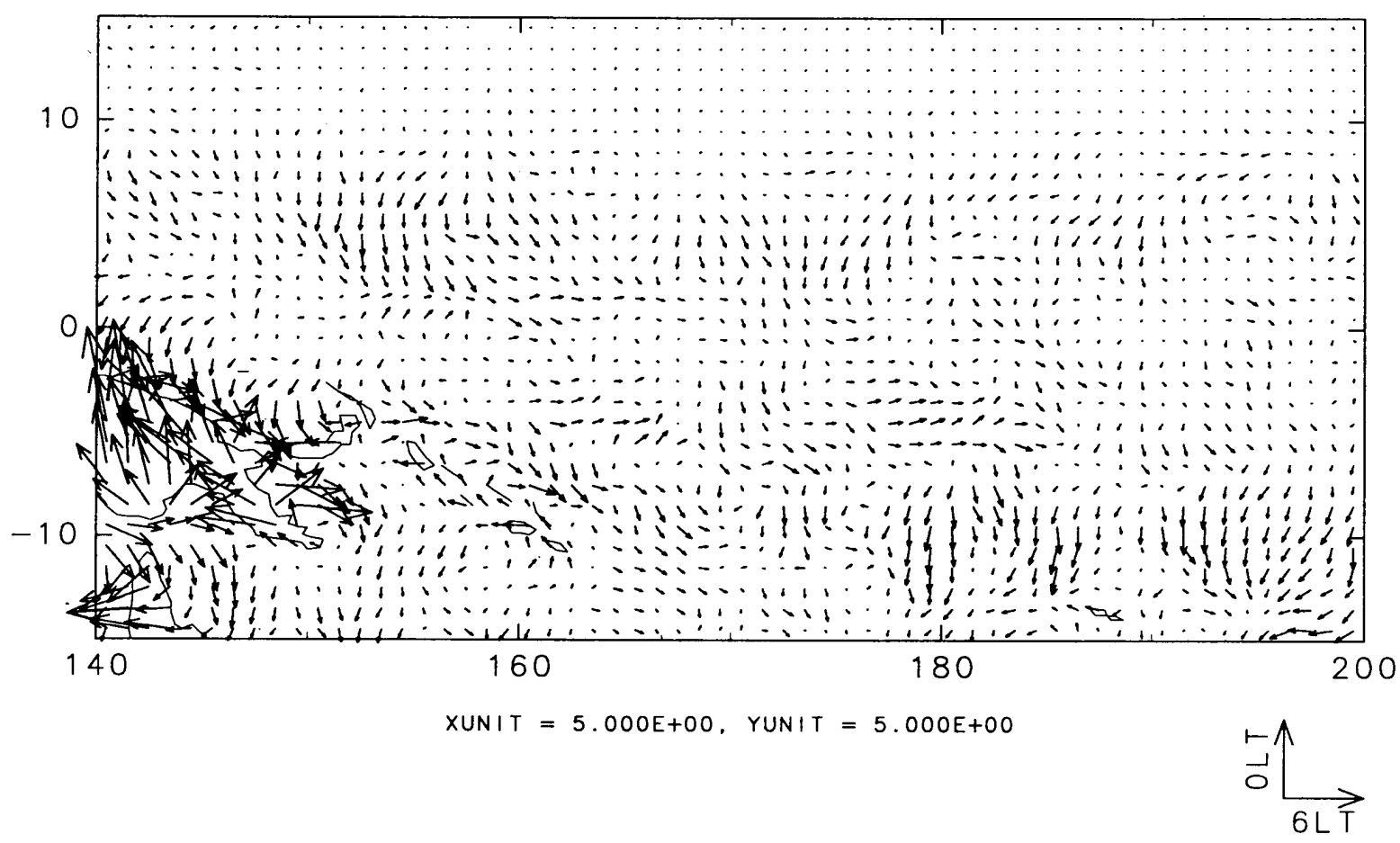

Fig. 8. Amplitudes and phases of diurnal components of $I_{C}$ represented by vector forms in the open oceanic regions east of $140^{\circ} \mathrm{E}$ in July (a) and January (b). Units of amplitudes are 5 shown in right-lower corner and the phase corresponds to the local time of the maximum $I_{C}$. 

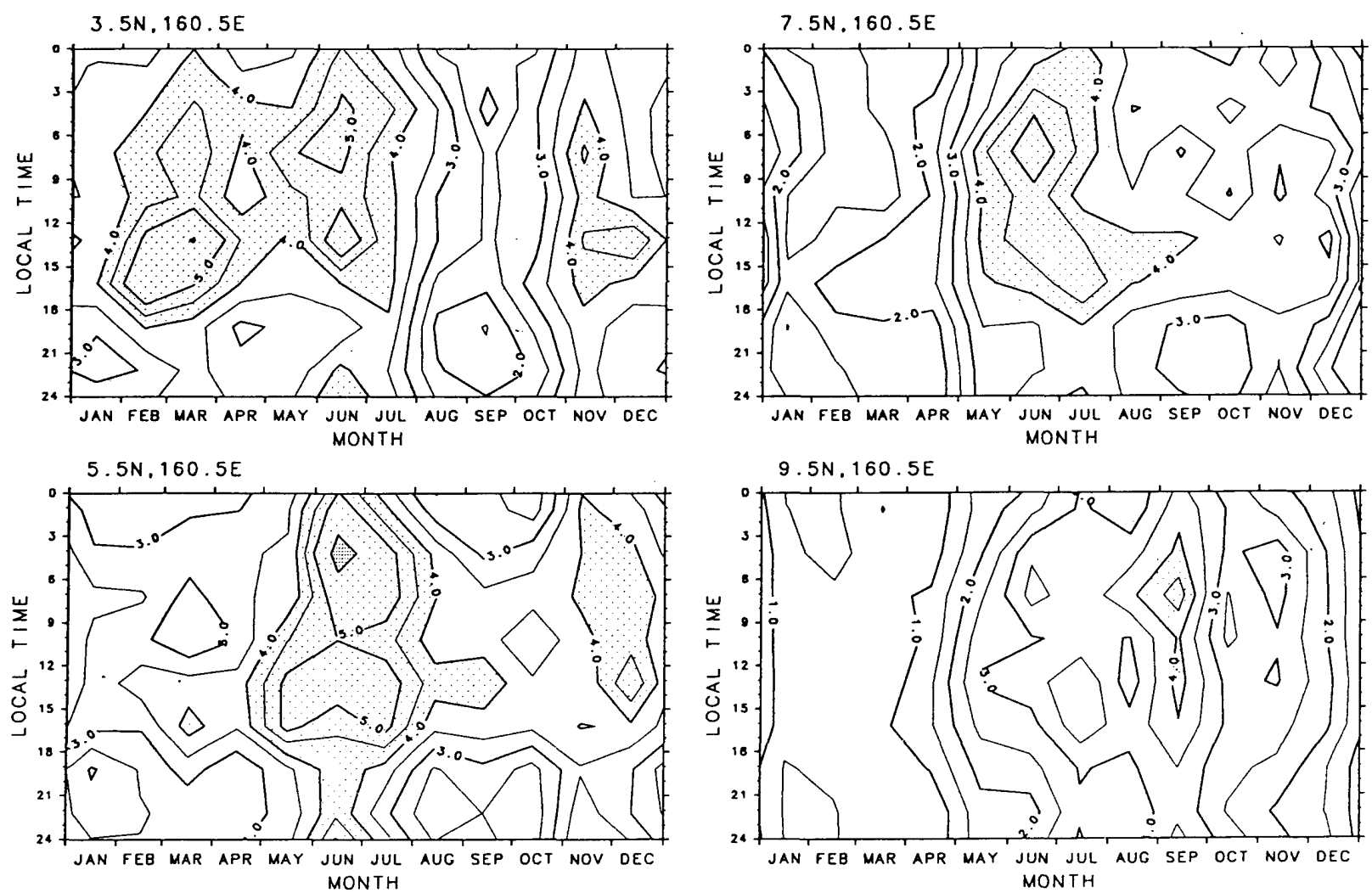

Fig. 9. Local time-season sections of $I_{C}$ at various latitudes over the ITCZ.
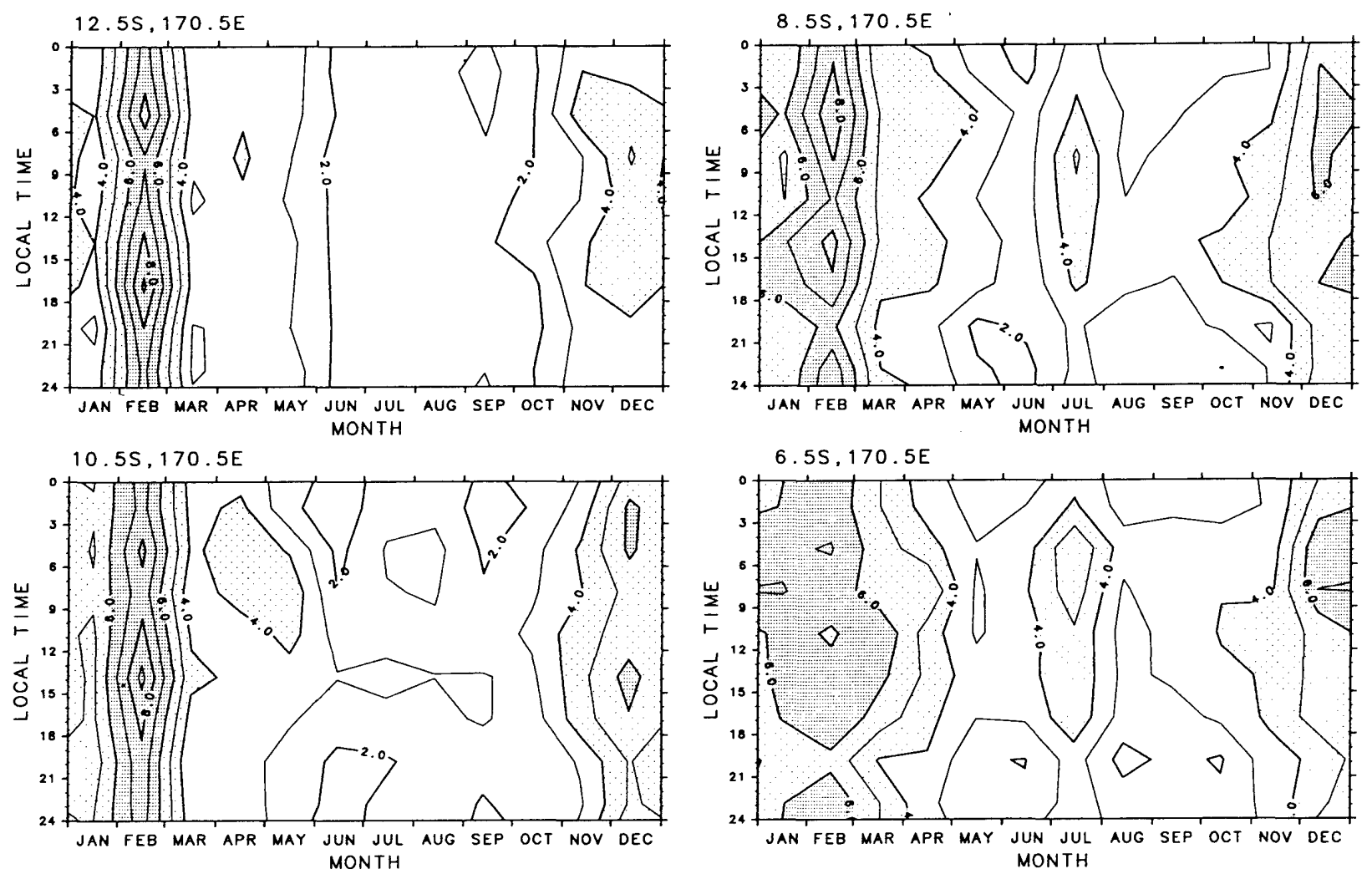

Fig. 10. Local time-season sections of $I_{C}$ at various latitudes over the SPCZ. 

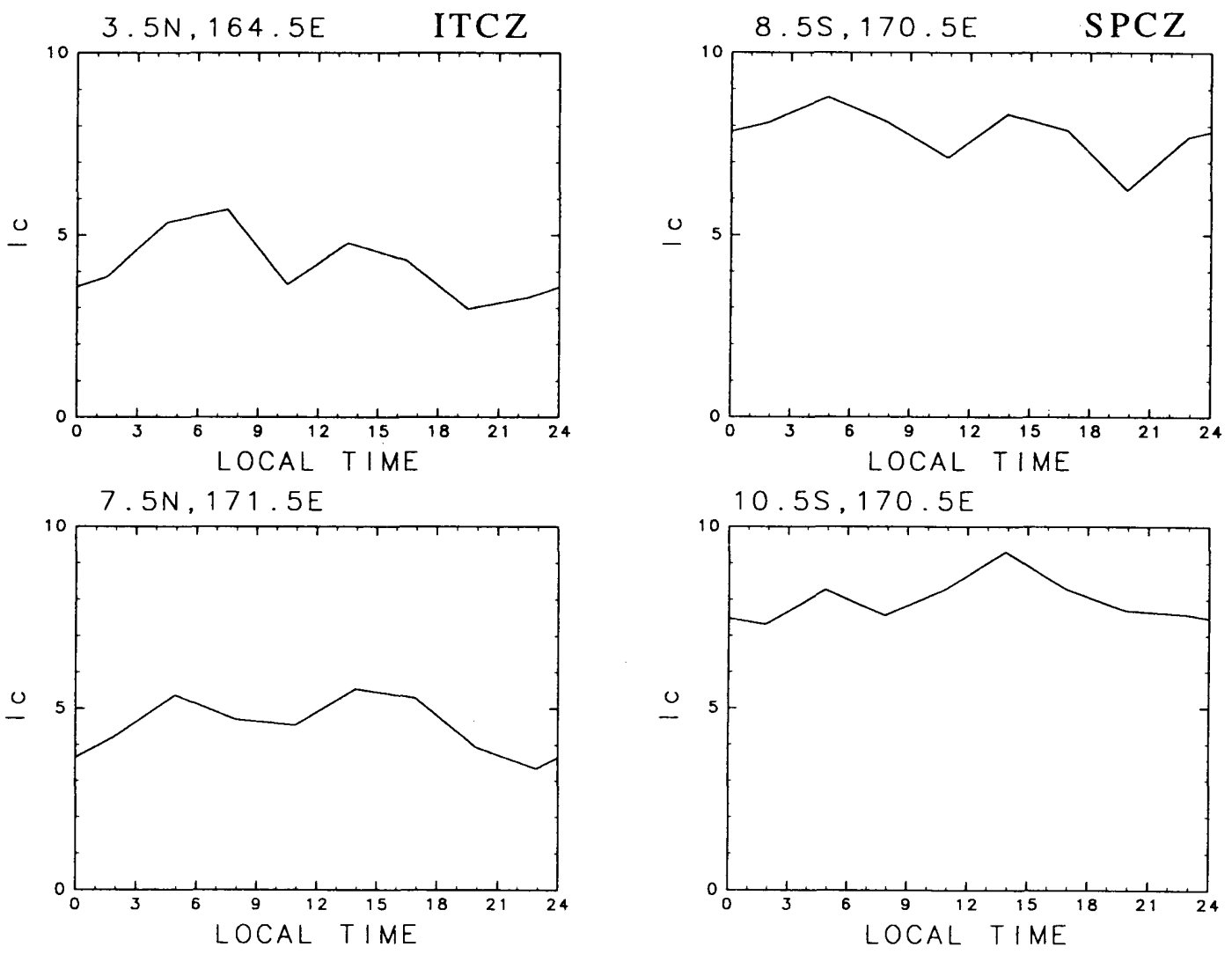

FIg. 11. Diurnal cycles of $I_{C}$ over the ITCZ in June (left) and over the SPCZ in February (right).

the SPCZ is slightly larger than over the ITCZ. Diurnal components over the SPCZ are more enhanced in January than in July. The maximum peak in January mostly occurs near noontime.

Amplitudes of the diurnal cycle over the ITCZ and the SPCZ are a few times smaller than those over the maritime continent regions. There exist nonuniform features of the diurnal variation in Fig. 8, but it is not certain now whether these features are associated with real physical processes or due to noise which was not fully smoothed out by the analysis. More detailed analysis should be done in future to examine these variations.

Figure 9 shows local time-season sections of $I_{C}$ at several latitudes in $160.5^{\circ} \mathrm{E}$, corresponding to the ITCZ. Convection over the ITCZ is generally active during the northern summer, but inactive during winter. Convection over the ITCZ has a dominant peak in the morning in general, but there is another peak in the afternoon during active convection seasons.

Figure 10 shows similar sections of $I_{C}$ over the SPCZ. The SPCZ at $170.5^{\circ} \mathrm{E}$ is predominant during the northern winter (southern summer), especially during February. In February, the convection has double peaks at about $5 \mathrm{LST}$ and $14 \mathrm{LST}$. The SPCZ becomes slightly enhanced in July at $6.5^{\circ} \mathrm{S}-8.5^{\circ} \mathrm{S}$ with the maximum amplitude in the morning. The diurnal modulation of the convective activity over the ITCZ and the SPCZ is weaker than that over the maritime continent regions.

Figure 11 shows diurnal cycles of $I_{C}$ over the ITCZ in June and those over the SPCZ in February. $I_{C}$ values over the ITCZ and the SPCZ have two peaks around 5-8 LST and 13-15 LST, as suggested from Figs. 9 and 10. The results in Figs. 9 , 10 and 11 imply that there exist semi-diurnal components of the convective activity over the ITCZ and the SPCZ.

Figure 12 shows horizontal distributions of the semi-diurnal component in July and January over $15^{\circ} \mathrm{N}-15^{\circ} \mathrm{S}, 140^{\circ} \mathrm{E}-160^{\circ} \mathrm{W}$. Larger semi-diurnal variations can be seen over the ITCZ and the SPCZ than over other oceanic regions. The Fourier analysis shows that the semi-diurnal component over the ITCZ and the SPCZ has a maximum near 4-5 LST (and also at 16-17 LST). The semi-diurnal component over the ITCZ is larger than that over the SPCZ in July, but the latter becomes larger than the former in January. The amplitude of the semidiurnal component is about a half of the diurnal component. Similar irregular features as in Fig. 8 are also found in Fig. 12.

Augstine (1984) found the existence of the semidiurnal component in satellite-inferred rainfall for August 1979 in the tropical eastern Pacific. He 
(a) HALF DAY VARIATION OF I C

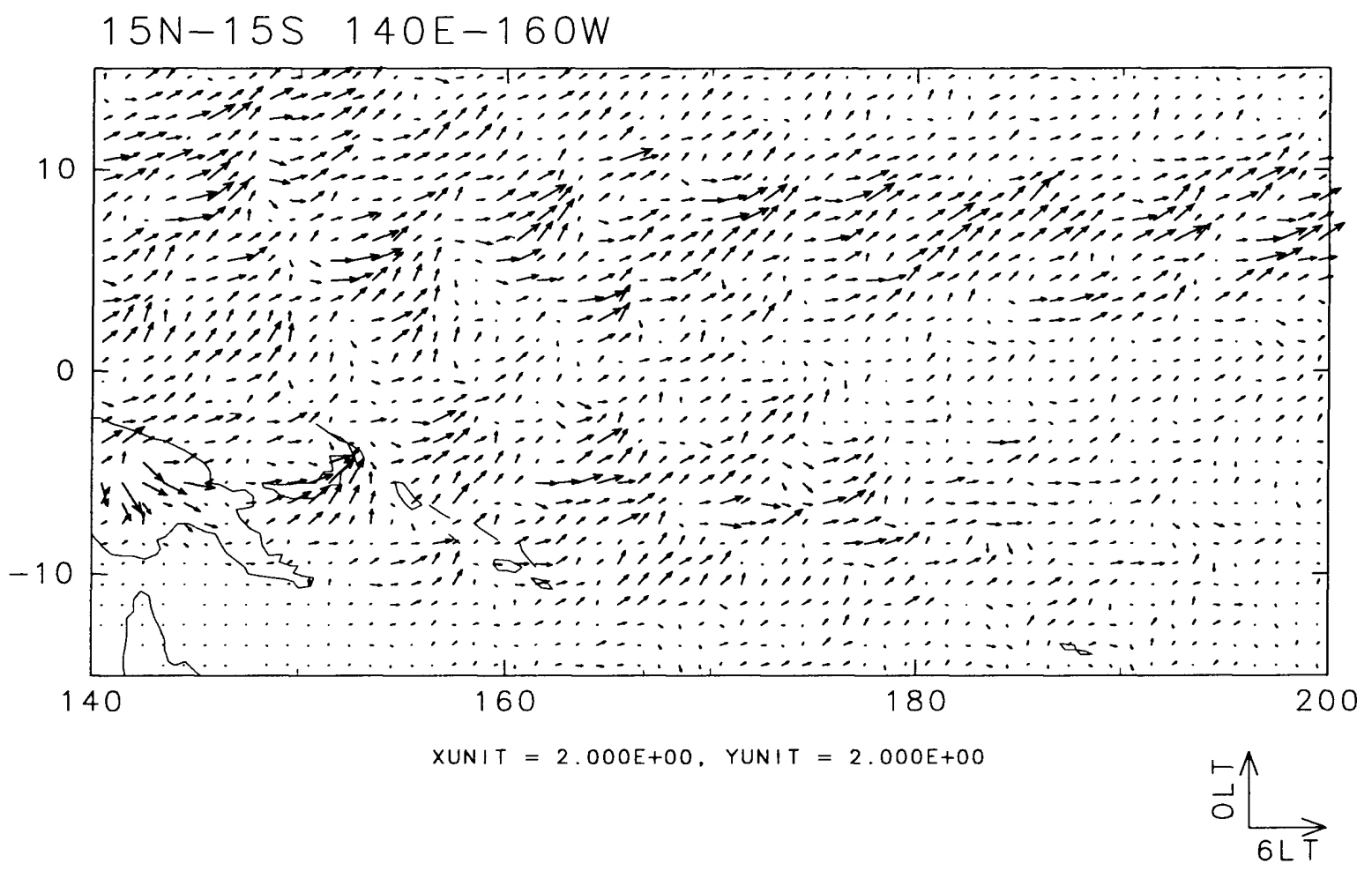

(b) HALF DAY VARIATION OF I C

$15 N-15 S \quad 140 E-160 W$

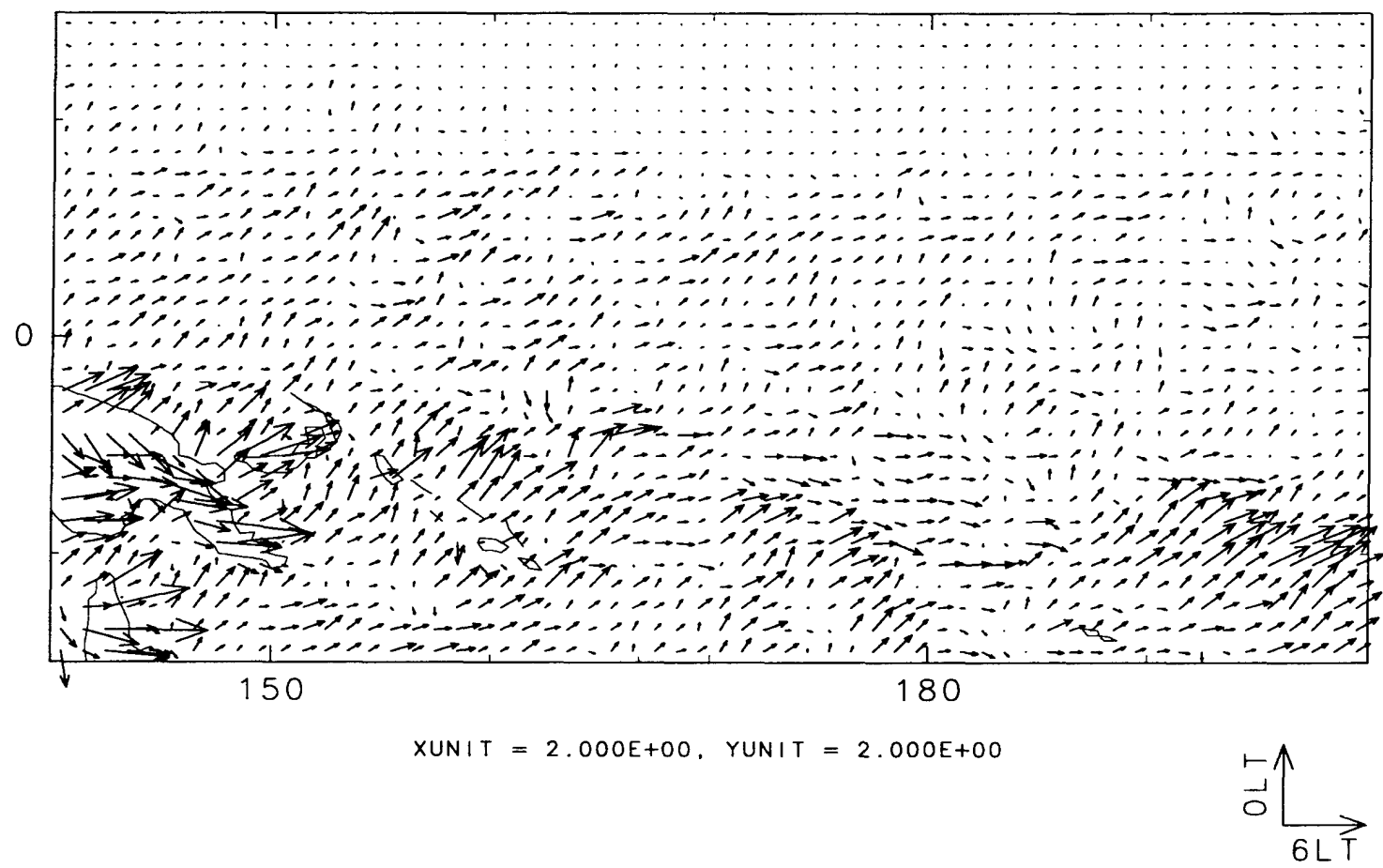

Fig. 12. Amplitudes and phases of semi-diurnal components of $I_{C}$ represented by vector forms in the open oceanic regions east of $140^{\circ} \mathrm{E}$ in July (a) and January (b). Units of amplitudes are 2 shown in right-lower corner and the phase corresponds to the local time of the maximum $I_{C}$. 
showed that the semi-diurnal component has a maximum around 4-5 LST and 16-17 LST which generally corresponds to the results obtained in this study, although his analysis period and region are different from ours. Albright et al. (1985) also obtained the double peaks of satellite-inferred rainfall over the SPCZ for January-February 1979. They found that the morning peak is mostly due to the deepest clouds with tops colder than $208 \mathrm{~K}$ (above the $175-\mathrm{hPa}$ level), but the afternoon peak is attributed to clouds with tops in the $253 \mathrm{~K}-218 \mathrm{~K}$ (400 to $200 \mathrm{hPa}$ ). These results imply a possibility that the double peaks of $I_{C}$ obtained in this study may result from a mixture of different types of clouds, but further analyses using different threshold $T_{B B}$ are needed in future.

\section{Summary and conclusions}

Diurnal variations of convective activities in the tropical western Pacific are analyzed based on 3hourly GMS- $T_{B B}$ data for 9 years. Large diurnal variations of convection exist over the Indochina Peninsula, the Tibetan Plateau and northern Australia, the maritime continent regions, the Bay of Bengal and the South China Sea. Moderate amplitudes of diurnal variations are also found over the ITCZ and the SPCZ.

Over continents and large islands, the convection attains the maximum intensity in late afternoon to evening, probably due to strong surface heating during the daytime. Over sea areas near large islands in the maritime continent regions, the maximum convective activity generally occurs in the morning.

Houze et al. (1981) analyzed convection in the vicinity of northern Borneo based on the radar and satellite observations obtained during the WMONEX and found a regular diurnal cycle in that region. They showed that convection is enhanced near midnight over land, but in the morning over sea. They concluded that the offshore convection is enhanced by the convergence of the land breeze from Borneo with the low-level northeasterly monsoon flow. Our results for the diurnal cycles in the vicinity of large islands over the maritime continent regions are generally consistent with their results. However, our results indicated that the diurnal variations in the offshore convection over the maritime continent are predominant not only during active monsoon seasons but also during transition periods between summer and winter monsoons and that phases of the enhancement of the convection vary in different locations and seasons. The interaction between local circulations generated due to land-sea heat contrast and the large-scale environmental circulations such as monsoonal or non-monsoonal flows may play an important role in generating the large diurnal cycles of the offshore convection in the vicinity of large islands. The detailed structure of the atmospheric circulations associated with the diurnal cycle over the maritime continent regions should be further investigated.

There exist large amplitudes of diurnal variations during Indian monsoon seasons over the head of the Bay of Bengal, and the maximum convection takes place in the afternoon. Complicated land-sea contrast surrounded by the Indian Subcontinent and the Indochina Peninsula may affect the diurnal cycle over this region, but further detailed analysis using upper air observation data would be needed to understand the mechanism of the diurnal cycle. The diurnal cycle of convection becomes predominant during summer and fall over the South China Sea and the maximum convective activity occurs near local noontime.

Although diurnal variations are less pronounced over the open oceanic regions east of $150^{\circ} \mathrm{E}$ than over the maritime continent regions, there exists the diurnal cycle over the active convection regions such as the ITCZ and the SPCZ with amplitudes a few times smaller than over the maritime continent regions. $I_{C}$ over the ITCZ and the SPCZ has its maximum intensity generally in the morning but the secondary maximum of $I_{C}$ occurs in the afternoon, indicating the existence of the semi-diurnal variations. The Fourier analysis of the second component (semi-diurnal variation) shows that there exist semi-diurnal variations of $I_{C}$ over the ITCZ and the SPCZ, suggesting the existence of semi-diurnal variations of convective activity, but further analyses using different threshold values of $T_{B B}$ and other data such as radar echoes may be needed to determine the semi-diurnal variation of convection.

The results of the morning maximum of the convective activity over the ITCZ and the SPCZ obtained in this study are consistent with those by Gray and Jacobson (1977), McBride and Gray (1980) and Murakami (1983). Gray and Jacobson (1977) hypothesized that the diurnal cycle in deep convection over the oceanic areas may result from day versus night variations in tropospheric radiative cooling between the convective region and its surrounding cloud-free region.

Brier and Simpson (1969) have shown that there exist semi-diurnal variations of cloudiness and rainfall at Batavia $\left(6.80^{\circ} \mathrm{S}, 106.45^{\circ} \mathrm{E}\right)$, with peaks near sunrise and sunset. They suggested that the semidiurnal variations of cloudiness and rainfall are related to a semi-diurnal solar atmospheric tide.

Although several hypotheses have been proposed to explain the mechanism of the diurnal and semidiurnal variations over the tropical oceanic regions as mentioned above, further detailed observational and modeling studies may be required to confirm those hypotheses. The TOGA/COARE (Tropical Ocean Global Atmosphere/Coupled Ocean Atmosphere Research Experiment) has been conducted 
over the warm water pool in the tropical western Pacific during November 1992-February 1993 and various types of observations in the atmosphere and ocean were obtained. It may be quite desirable to analyze the diurnal cycle of convection by using the TOGA/COARE data in near future.

\section{Acknowledgments}

The authors would like to thank Dr. M. Murakami and Mr. K. Takahashi for providing GMS $T_{B B}$ data and for their valuable suggestions about the data processing. They also wish to extend their thanks to Dr. T. Oki for providing maps of diurnal cycles of precipitation over Malaysia. The comments and discussions by Dr. Y.N. Takayabu were very helpful.

\section{References}

Albright, M.D., E.E. Recker, R.J. Reed and R. Dang, 1985: The diurnal variation of deep convection and inferred precipitation in the central tropical Pacific during January-February 1979. Mon. Wea. Rev., 113, 1663-1680.

Aspliden, C.I., Y. Tourre and J.C. Sabine, 1976: Some climatological aspects of West Africa disturbance lines during GATE. Mon. Wea. Rev., 104, 10291035.

Augustine, J.A., 1984: The diurnal variation of largescale interred rainfall over the tropical Pacific Ocean. Mon. Wea. Rev., 112, 1745-1751.

Ball, J.T., S.J. Thoren and M.A. Atwater, 1980: Cloudcoverage characteristics during Phase III of GATE as derived from satellite and ship data. Mon. Wea. Rev., 108, 1419-1429.

Brier, G.W. and J. Simpson, 1969: Tropical cloudiness and rainfall related to pressure and tidal variations. Quart. J. Roy. Meteor. Soc., 95, 120-147.
Gray, W.M. and R.W. Jacobson, Jr., 1977: Diurnal variation of oceanic deep cumulus convection. Mon. Wea. Rev., 105, 1171-1188.

Gruber, A., 1976: An estimate of the daily variation of cloudiness over the GATE A/B area. Mon. Wea. Rev., 104, 1036-1039.

Haldar, G.C., A.M. Sud and S.D. Marathe, 1991: Diurnal variation of monsoon rainfall in central India. Mausam, 42, 37-40.

Houze, R.A., Jr., S.G. Geotis, F.D. Marks and A.K. West, Jr., 1981: Winter monsoon convection in the vicinity of north Borneo. Part I: Structure and time variation of the clouds and precipitation. Mon. Wea. Rev., 109, 1595-1614.

Maruyama, T., T. Nitta and Y. Tsuneoka, 1986: Estimation of monthly rainfall from satellite-observed cloud amount in the tropical western Pacific. J. Meteor. Soc. Japan, 64, 147-153.

Matsumoto, J., 1992: The seasonal changes in Asian and Australian monsoon regions. J. Meteor. Soc. Japan, 70, 257-273.

McBride, J.L. and W.M. Gray, 1980: Mass divergence in tropical weather systems, I, Diurnal variations. Quart. J. Meteor. Soc., 106, 501-516.

Murakami, M., 1979: Large-scale aspects of convective activity over the GATE area. Mon. Wea. Rev., 107, 994-1013.

Murakami, M., 1983: Analysis of the deep convective activity over the western Pacific and Southeast Asia, Part I: Diurnal variation. J. Meteor. Soc. Japan, 61, 60-76.

Niewwolt, S., 1968: Diurnal rainfall variation in Malaya. A.A.A.G., 58, 313-326.

Oki, T. and K. Musiake, 1994: Seasonal changes of the diurnal cycle of precipitation over Japan and Malaysia. J. Appl. Meteor., 33, (in press).

Ramage, C.S., 1964: Diurnal variation of summer rainfall of Malaysia. J. Tropical Geogr., 19, 62-68. 


\section{熱帯西部太平洋における対流活動の日变化}

\section{新田 就・関根創太}

(東京大学気候システム研究センター)

静止気象衛星「ひまわり」による 3 時間間隔、9 年間の $T_{B B}$ デー夕を用いて、熱帯西部太平洋域の対流活 動の日変化の解析を行った。対流活動の大きな日変化がインドシナ半島、チベット高原、北オーストラリ ア、海洋大陸域等の大陸や大きな島及びその周辺海域に存在する。また、べンガル湾と南シナ海にも大きな 日変化が存在する。一方、海洋大陸域ほど大きくはないが、熱帯収束帯 (ITCZ) と南太平洋収束帯 (SPCZ) にも日変化が見られる。日変化の特徵は季節によって变化し、対流活動が活発な季節に日変化の振幅も増 大する。

大陸上及び大きな島の上では、対流活動は午後遅くから夜にかけてピークに達するが、これは日中の地 表からの加熱によるものと思われる。一方、大きな島の周辺海域では、対流活動のピークは一般に午前中 に現れる。このような周辺海域の対流活動の日変化は、海陸風循環と大規模な一般風との相互作用によっ て作られているものと思われる。

ベンガル湾の北端海域の対流活動は夏のインドモンスーン期に大きな日変化を示し、午後に対流活動の ピークが現れる。南シナ海の対流活動の日変化は夏から秋にかけて顕著になり、正午頃ピークになる。

$\mathrm{ITCZ}$ と SPCZ の対流活動は一般に午前に最盛期に達するが、午後にもう一度活発になる。フーリエ解 析の結果、ITCZ や SPCZ 上には半日周期の変動が存在し、3-4 地方時と 15-16 地方時に対流活動が最大 となることがわかった。 